\title{
An overview of the hydropower production potential in Bangladesh to meet the energy requirements
}

\author{
Monirul Islam Miskat ${ }^{1^{*}}$, Ashfaq Ahmed ${ }^{2,3^{*}}$, Md Salman Rahman ${ }^{4}$, Hemal Chowdhury ${ }^{5}$, \\ Tamal Chowdhury ${ }^{1}$, Piyal Chowdhury ${ }^{6}$, Sadiq M. Sait ${ }^{7}$, Young-Kwon Park ${ }^{2+}$ \\ ${ }^{1}$ Department of Electrical and Electronic Engineering, Chittagong University of Engineering and Technology (CUET), Chattogram 4349, Bangladesh \\ ${ }^{2}$ School of Environmental Engineering, University of Seoul, Seoul 02504, Republic of Korea \\ ${ }^{3}$ Department of Chemical Engineering, COMSATS University Islamabad, Lahore Campus, Raiwind Road, 42000 Lahore, Pakistan \\ ${ }^{4}$ Department of Civil Engineering, Chittagong University of Engineering and Technology (CUET), Chittagong 4349, Bangladesh \\ ${ }^{5}$ Department of Mechanical Engineering, Chittagong University of Engineering and Technology (CUET), Chattogram 4349, Bangladesh \\ ${ }^{6}$ Chattogram Collegiate School \& College, Ice Factory Road, Chattogram, Bangladesh \\ ${ }^{7}$ CCITR-RI, King Fahd University of Petroleum \& Minerals, Dhahran-31261, Saudi Arabia \\ *These authors contributed equally to this work.
}

\begin{abstract}
Current environmental catastrophes generating from fossil fuel power generation has attracted the attention of energy planners to look for sustainable energy sources. Hydropower is one of the oldest energy sources that have been utilized all over the world to generate electricity, especially in remote areas. Being one of the most densely populated countries, the majority of power demand is fulfilled from fossil fuel. Despite having lots of rivers, Bangladesh has not explored its true potential. So, this paper presents a comprehensive review of the current hydropower potential in Bangladesh. Locations having hydropower potential is evaluated. Different technologies used for hydropower generation have been reviewed. Moreover, global hydropower potential has also been discussed in this study. Based on the economic and environmental study, it is found that small scale hydropower is most feasible in Bangladesh to provide sustainable energy. With a reasonable flow rate, 232 rivers of Bangladesh can be utilized small scale hydropower generation as well as ensuring energy security for remote people. The current study is believed to provide useful information in advancing the generation of hydropower based electricity in Bangladesh
\end{abstract}

Keywords: Bangladesh, Hydropower, Hydropower development, Renewable Energy

\section{Introduction}

Currently, approximately $11 \%$ of the world population which accounts for 840 million people still lack access to electricity. Around $97 \%$ of the people population who lack quality electricity live in developing countries. Furthermore, global electricity demand will be doubled within 2050 [1-4]. International Energy Agency (IEA) report stated that about $16 \%$ of the world inhabitants won't have access to electricity by 2030 [5]. Providing rural areas with electricity is a major issue in some countries, particularly those in Asia [6]. Besides, the sustainable generation of power has also gained attention in recent years. Ongoing environmental issues such as global warming and Greenhouse Gas (GHG) has encouraged global policymakers to shift towards clean power generation [6]. According to IEA, $2.5 \%$ of the world's total primary energy is supplied by Hydropower in 2018 [7]. Renewable energy resources open up the possibility of clean fuel technologies and thus can be a useful solution to combat issues such as global warming [8-13]. Among different renewable energy resources, hydropower is one of the cleanest sources of energy that can be utilized to address the electricity need in rural areas. Hydropower has certain advantages such as low operation cost, low emission, low fuel cost, low price, and higher plant(s) life than conventional power plants [14]. Hydropower can be categorized based on power output,
This is an Open Access article distributed under the terms of the Creative Commons Attribution Non-Commercial License (http://creativecommons.org/licenses/by-nc/3.0/) which permits unrestricted non-commercial use, distribution, and reproduction in any medium, provided the original work is properly cited.

Copyright (C) 2021 Korean Society of Environmental Engineers
Received September 16, 2020 Accepted November 18, 2020

${ }^{\dagger}$ Corresponding author

Email: catalica@uos.ac.kr

Tel: +82-2-6490-2870 Fax: +82-2-6490-2859

ORCID: 0000-0002-2271-0869 
Table 1. Subdivision of Hydro-Power Based on Different Criteria

\begin{tabular}{|c|c|}
\hline Classification & Description \\
\hline \multicolumn{2}{|l|}{ 1) Power Output [15-19] } \\
\hline Large & Higher than $100 \mathrm{MW}$ \\
\hline Medium & 10-100 MW \\
\hline Small & 1-10 MW \\
\hline Mini & $100 \mathrm{KW}-1 \mathrm{MW}$ \\
\hline Micro & 5-100 KW \\
\hline Pico & Less than $5 \mathrm{KW}$ \\
\hline \multicolumn{2}{|l|}{ 2) Head Range [20-22] } \\
\hline Higher head & $100 \mathrm{~m}$ and above \\
\hline Medium Head & $30-100 \mathrm{~m}$ \\
\hline Lower head & $2-30 \mathrm{~m}$ \\
\hline 3) The operating system[23] & $\begin{array}{l}\text { Considering different parameters various types and sizes of a hydropower plant can be built. Operating } \\
\text { parameters such considering head as well as flow rate, hydropower plants can be of three types. }\end{array}$ \\
\hline Run of river type & $\begin{array}{l}\text { In this scheme, power is generated by the natural flow of water, and the flow of water is not controlled. } \\
\text { Naturally, it is subject to water shortage during the summer season, and water is filled in a reservoir } \\
\text { in the rainy season. Whenever there is a high flow rate exceeding the capacity, then there is water } \\
\text { spillage, which means loss of energy. }\end{array}$ \\
\hline Reservoir type & $\begin{array}{l}\text { In this scheme, an excess portion of water is stored in the reservoir, and power generation is regulated } \\
\text { based on demand. It is dependent on the topology of the land where the plant will be built. }\end{array}$ \\
\hline Pumped Storage type & $\begin{array}{l}\text { This scheme utilizes electricity to pump up water from storage located at the bottom portion of } \\
\text { a site to the top of the storage. This type of hydro plant works not only as an energy source but } \\
\text { also as an energy storage device. But it is quite arduous to find a suitable location for a pumped } \\
\text { storage type plant. }\end{array}$ \\
\hline
\end{tabular}

head range, and operating system usages. Table 1, shows the different classification of Hydro-Power based on the above-mentioned criteria.

Among these technologies, Small Scale HydroPower (SSHP) is the purest form of energy since it emits less pollutants than other Large Scale HydroPower(LSHP) [24]. Besides LSHP has the disadvantage of ecological damage and large transmission loss due to long overhead transmission lines [25, 26]. For these reasons, investors have lost interest while SCHP is gaining worldwide attention. Another significant hydropower technology that has attracted attention is pumped hydro technology [27]. In this technology, water is stored in a high-head variation storage reservoir which is constructed in parallel to a large river. When energy demand is low or there is the availability of a large quantity of water, water is pumped and stored in the reservoir. This reserved water is used when there is a scarcity or when there is a need to generate electricity [27]. In 2018, the total primary energy consumption of Bangladesh was 47 Mtoe and on average 293 kgoe (kilogram oil equivalent) energy is used [28]. At the end of June 2018, only 12.72 TCF of natural gas is in reserve and 3,100 million tonnes of coal is in reserve [28]. The total energy supply by various energy resources in Bangladesh for 2017-2018 is shown in Fig. 1 [28]. From Fig. 1 it is depicted that a major portion of energy comes from natural gas.

Both the usage of coal as well as natural gas has stepped up from 2007 [29, 30]. For power generation, natural gas demand is rising day by day and power plants consume nearly $40 \%$ of the overall gas production [31]. Furthermore, there is a profound gap in production as well as demand.

In 2019 maximum demand was 13,044 MW while the maximum peak generation was12893 MW. Only Natural gas contributes to $68.49 \%$ of the total energy generation [32]. This dependency on fossil fuel is creating environmental hazards and also sustainability in this sector is deteriorating. Bangladesh government wants to meet $10 \%$ of its electricity demand by utilizing renewable sources [32, 33]. To foster the usage of sustainable sources

Oil Natural Gas Coal $\square$ RE Electricity $\square$ Biomass

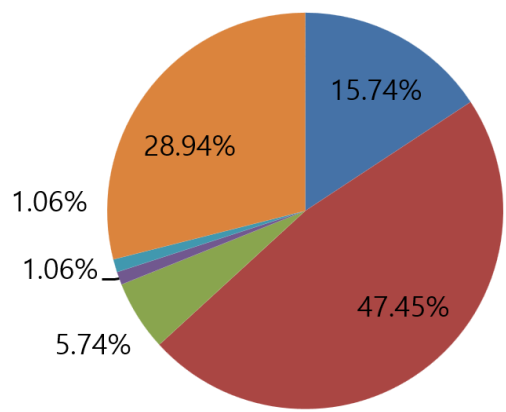

Fig. 1. Total energy supplied (\%) by various resources in Bangladesh [28]. 
and reduce the dependency on petroleum products, the Government of Bangladesh has undertaken some measures [34]. Not only public organizations but also private institutions are working relentlessly to harness energy from renewable energy resources. The main objective of this paper is to spotlight on the present condition of hydro based energy generation growth in Bangladesh. This study not only highlights hydro based energy generation growth but also several implications. The current aim of this article is to highlight the present situation of Hydro energy development in Bangladesh. There are hardly any review studies for Bangladesh which address hydro energy development in Bangladesh. So, this study highlights these issues and points to some implications.

\section{Hydro Potential in Bangladesh}

Hydro energy is one the cleanest source of energy compared to other conventional energy sources that are used for power gen- eration on a massive scale. As both costs of supply and GHG emissions are quite low, this makes hydropower generation an excellent choice for energy harvesting. Bangladesh is bestowed with lots of rivers and rivers play an important role in the livelihood of the people of Bangladesh. Fig. 2 denotes the river network of Bangladesh [35].

Though Bangladesh is bestowed with lots of rivers, hydropower generation is not up to the mark due to the absence of high head and high flow rate. Resources are limited and proper utilization of these can lead to the generation of sustainable power for fulfilling the ever-increasing demand. Around $20 \%$ of the world's total electricity comes from hydro energy [36]. Bangladesh is also trying to maximize hydropower generation by taking various measures. Kaptai power plant was the first hydropower plant in Bangladesh built with a capacity of 230MW. During rainy seasons, excess rain creates an opportunity to produce more hydropower and that's why Bangladesh Power Development Board (BPDB) is planning to establish an additional $100 \mathrm{MW}$ capacity plant in this area. Along with large scale hydropower plants, micro-hydropower

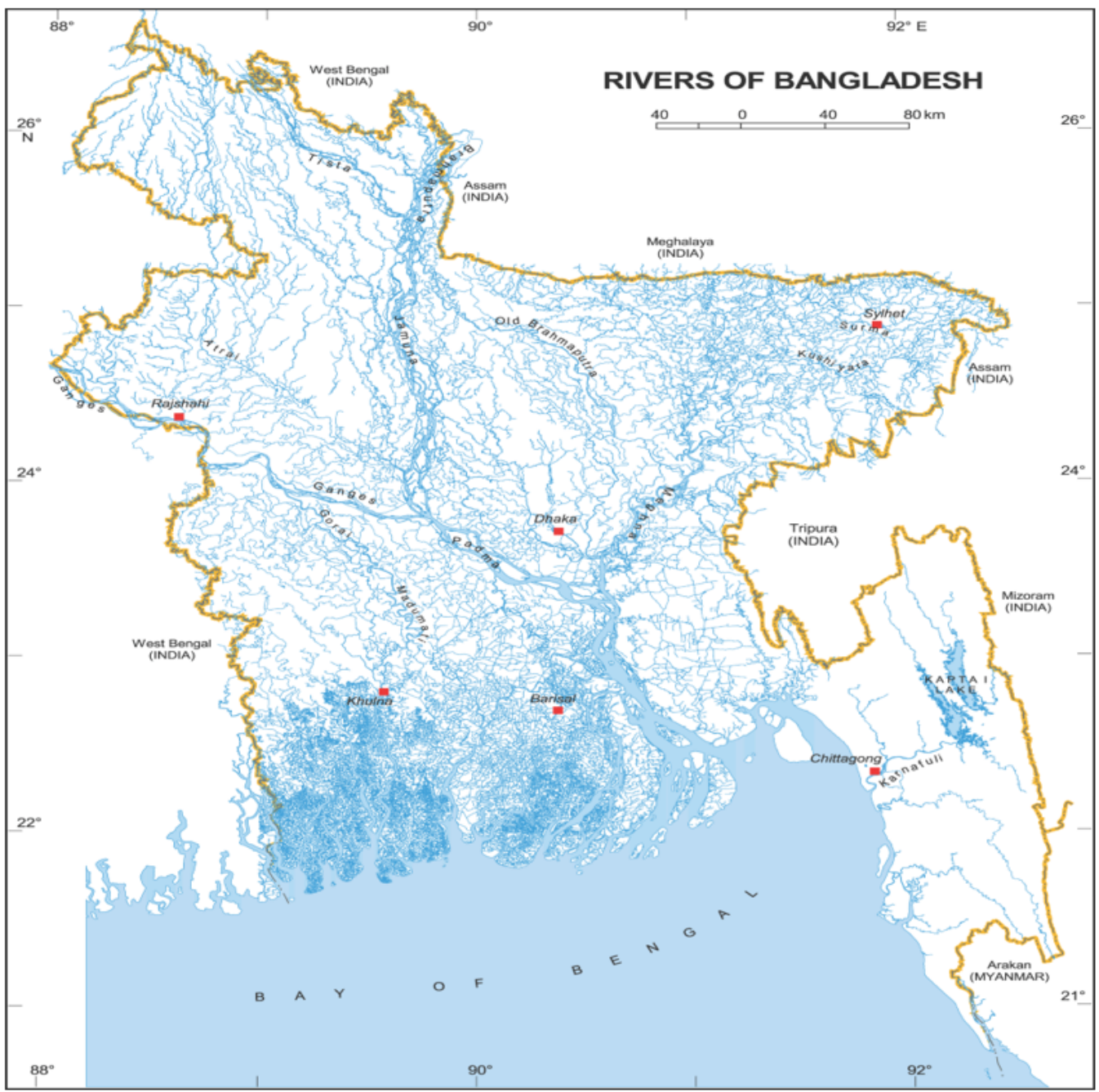

Fig. 2. Map of the river network of Bangladesh [35]. 
Monirul Islam Miskat et al.

Table 2. Hydro-power Potential in Meghalaya Rivers of the Northeast Region [39]

\begin{tabular}{lcccc}
\hline \multirow{2}{*}{ River } & Site & Catchments area $\mathbf{( k m}^{\mathbf{2}}$ & \multicolumn{2}{c}{ Estimated annual output } \\
\cline { 3 - 4 } Someswari & Dugapur & 2134 & $\mathbf{( M W )}$ & 43 \\
Jadukata & Saktiakhola & 2513 & 13 & 115 \\
Jhalukhali & Dalura & 448 & 5 & 45 \\
Sarigoyain & Lalakhal TG & 802 & 3 & 30 \\
Lubha & Mugulgul & 724 & 3 & 27 \\
Dhalai & Khalasadaq & 342 & 2 & 15 \\
Umium & Chalelhnapur & 518 & 2 & 20 \\
Bhugai & Hatipagar & 453 & 1 & 6 \\
Darang & Ghosegaon & 381 & 1 & 6 \\
Total & & & 35 & 307 \\
\hline
\end{tabular}

Table 3. Prospective Sites for Micro Hydropower Development in Chittagong Hill Tracts [38, 39].

\begin{tabular}{|c|c|c|c|c|}
\hline Location & $\begin{array}{c}\text { Cross Sectional area } \\
\left(\mathrm{m}^{2}\right)\end{array}$ & $\begin{array}{l}\text { Lowest flood level } \\
\text { (m) }\end{array}$ & $\begin{array}{l}\text { Highest flood level } \\
\text { (m) }\end{array}$ & $\begin{array}{r}\text { Power } \\
(k W)\end{array}$ \\
\hline Nunchari Tholi Khal, Khagrachari & 11 & 0.06 (May) & 3 & 5 \\
\hline Sealock Khal in Bandarban & 25 & 0.15 (April) & 4 & 30 \\
\hline Taracha Khal in Bandarban & 35 & 0.1 (April) & 6 & 20 \\
\hline Rowangchari Khal in Bandarban & 30 & 0.1 (April) & 5 & 10 \\
\hline Hnara Khal in Kamal Chari, Rangamati & 20 & 0.15 (May) & 4.20 & 10 \\
\hline Hnara Khal in, Hang Khrue Chara M ukh, Rangamati & 25 & 0.12 (May) & 4 & 30 \\
\hline Monjaipara micro hydropower Unit & 15 & 0.50 & 1 & 10 \\
\hline Bamer Chara irrigation Project & & 10 & & \\
\hline
\end{tabular}

plants also attracted the attention of people. The first small-scale micro-hydropower plant of Bangladesh was established in Bandarban to meet the energy demand of 140 households and a temple with a capacity of $10 \mathrm{~kW}$ Government established a 50 kW micro-hydropower plant in Barkal Upazila, Rangamati [36].

Some potential sites for harvesting hydropower have been investigated in Bangladesh. Sustainable Rural energy project surveyed locations for micro-hydro plants in Chittagong district and it was estimated to be 135.5 MW. Sangu and Matamuhuri river basin comprising 87MW and $80 \mathrm{MW}$ of hydro potential capacity is considered suitable for power generation at an affordable cost. The expected annual energy production of the Sangu and Matamuhuri project will be $300 \mathrm{GW} /$ year and $200 \mathrm{GW} /$ year respectively. Brahmaputra river basin has a massive potential of 1,400 MW for large scale power generation [37].

The northeastern region of Bangladesh also has a promising potential to contribute to the hydro energy sector in Bangladesh. That's why, Northeast Regional Water Management Project (FAP-6) under Flood Action Plan (FAP), conducted a preliminary assessment to find out the potential sites and rivers to produce hydro energy. The project mainly aimed at finding the best feasible sites to establish runoff, low head hydropower plants [38]. Potential sites along with flow data are depicted in Table S1 (supplementary data). Considering $5 \mathrm{~m}$ of head along with mean monthly discharges of these ten sites, they found the overall potential of $161 \mathrm{MW}$ and energy production $1,410 \mathrm{GWh} /$ year. Nine rivers were also found to be suitable from this study. Normally, during the rainy season, there is a high discharge of water and in the winter season, rivers almost dry out. So, power generation will significantly decrease in the winter season. From these nine rivers, it was estimated that annually they will produce $307 \mathrm{GWh}$ and estimated power output will be $35 \mathrm{MW}$. Potential energy, as well as catchment areas of these rivers, are shown in Table 2 [39].

In 1981, BPDB and Bangladesh Water Development Board (BWDB) conducted a survey across the country to find out the possible hydro sites for small-scale hydropower plants. This study found 19 feasible sites for the generation of hydro-electricity which are shown in Table 3 [38, 39].

After three years, in 1984, a team of Chinese experts found 12 potential sites in the hill tract areas of Bangladesh to produce hydropower. Among these sites Mahamaya Chara which is located in Mirsharai, Chittagong has the highest potential to develop a small-scale hydropower plant. From feasibility study of Mahamaya Chara it was found that hydroelectricity can be produced throughout the year except in April and May. There is a proposal to construct a dam in Mahamaya Chara which will encompass an area of $10.5 \mathrm{~km}^{2}$ to reserve water and provide irrigation facilities. A mini-hydro plant will be established at the foot of dam and reservoir water will run this plant [38]. The Hill tract of Bangladesh has enormous potential for hydro energy because of numerous small rivers and canals. Local Government Engineering Department (LGED) has 


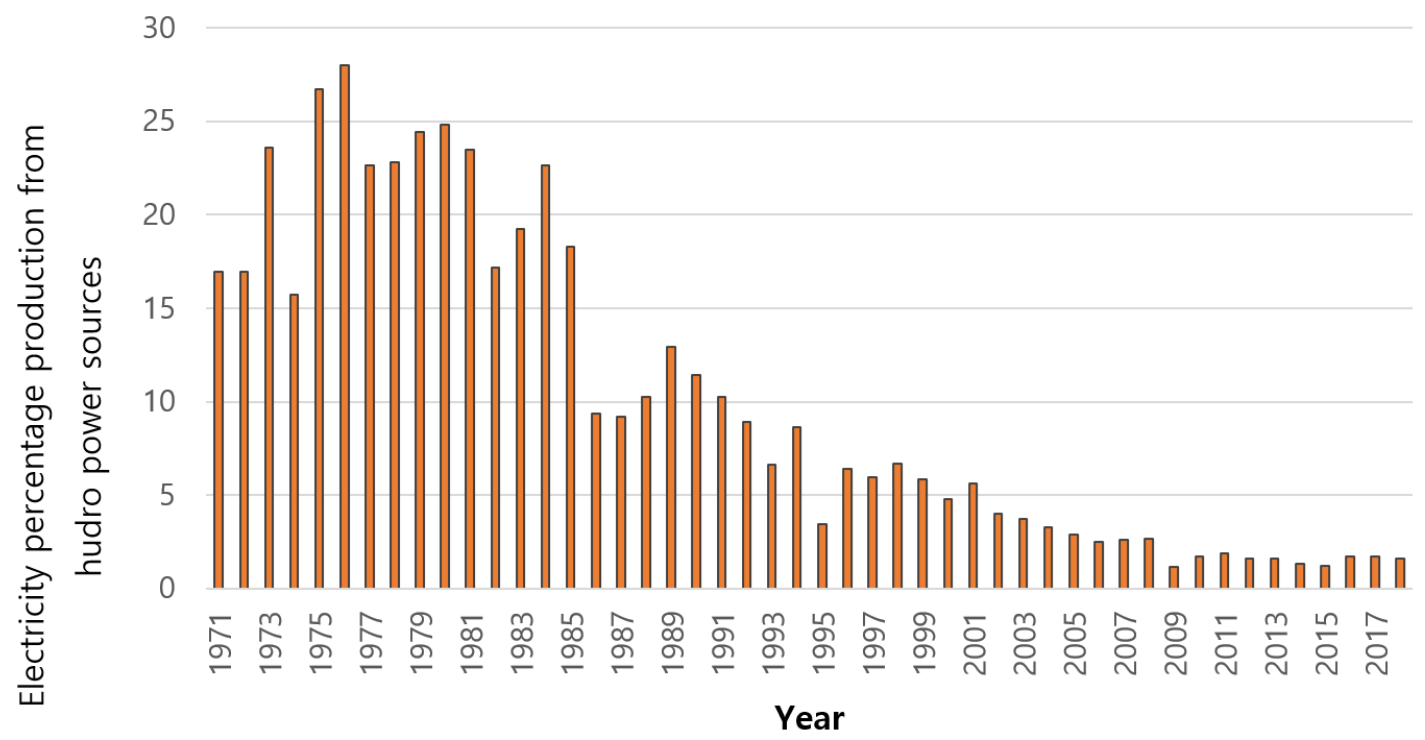

Fig. 3. Electricity percentage production from hydropower sources in Bangladesh from 1971 to 2018 [36].

Table 4. Potential Small Hydropower Sites Identified by BPDB and BWDB [38, 39].

\begin{tabular}{ccc}
\hline District & River/Stream & $\begin{array}{c}\text { Potential of electrical } \\
\text { energy }(\mathrm{kW})\end{array}$ \\
Chittagong & Faiz Lake & 4 \\
Chittagong & Choto Kumira & 15 \\
Chittagong & Hinguli Chara & 12 \\
Chittagong hilltracts & Sealock & 81 \\
Chittagong & Lungichara & 10 \\
Chittagong & Budichara & 10 \\
Sylhet & Nikhan Chara & 26 \\
Sylhet & MadhabChara & 78 \\
Sylhet & Banga Pani Gung & 616 \\
Jamalpur & Bhugai Kangsa & $60 \mathrm{~kW}$ for 10 months \\
& & 48 for 2 months \\
Jamalpur & Marisi & $35 \mathrm{~kW}$ for 10 months \\
Dinajpur & Badul & 24 \\
Dinajpur & Chawai & 32 \\
Dinajpur & Talma & 24 \\
Dinajpur & Pathraj & 32 \\
Dinajpur & Tangon & 48 \\
Dinajpur & Punar Haba & 11 \\
Rangpur & Bari Khora & 32 \\
Rangpur & Ful Kumar & 24 \\
\hline & & \\
\hline
\end{tabular}

been trying to employ hydro energy resources to meet the energy demand in hill tract areas. As a result, LGED located several prospective sites of remote hill tract region of Bangladesh. Prospective sites along with power generation potential are given in Table 4 [38, 39].

Sitakunda, Richang, as well as Toibang of Chittagong, have the potential to establish micro-hydropower plant [36]. Teesta barrage is the largest irrigation project in Bangladesh along with 19 potential sites for power generation. An overall percentage of electricity production from hydropower resources in Bangladesh from 1971 to 2018 is shown in Fig. 3.

\section{Small Scale Hydropower Technology}

Small-scale hydropower technology is a major subclass of renewable and sustainable energy and is getting worldwide attention due to its major advantage from an environmental perspective, the abundance of resources, and increased efficiency. Bangladesh has a huge possibility of SSHT because of its plethora of rivers and canals which provide abundant water for hydropower generation. Despite this, SSHT nearly contributes to $2.34 \%$ of electricity generation in Bangladesh [40]. To increase the SSHT generation potential it is required to review SSHT technology for its adoption in Bangladesh.

\subsection{General Structure and Principle of SSHT}

Hydropower plant has several benefits because of its large capacity of energy generation, size of the plant, opulence of resources, and ease of installation and maintenance compared to other energy resources [39]. But its existing efficiency and water power are not easy to extract without a proper generation system. The proper generation of SSHT principally depends on the head and flow $[41,42]$. Head refers to water pressure determined by the elevation difference of intake and turbine expressed as vertical distance or force per square area. Flow is defined by the rate with which the water passes, expressed as the volume of water per unit time. These two factors (head and flow) play a major role in the perform- 
ance of the turbine [43]. Major components of SSHT include water supply and penstock pipe, turbine, electronic controller, distribution system, and electrical load. SSHT's working principle can be summarized as two-stage:

Firstly, water from reservoir flow hits the pen stack pipe which ultimately hits the turbine runner by which the first energy extraction takes place.

Secondly, the turbine system drives the generator when the shaft has attached with it, which converts the hydraulic power to mechanical power, and the generator to convert the mechanical power to electricity. Finally, this power is distributed through load and grid.

To access the potentiality of SSHT it is necessary to find out the energy generation, hydropower, and mechanical power potentiality. The ratio of these, which is hydropower and mechanical power potentialities indicates the experimental efficiency of the SSHT. Researchers have shown how to determine the hydro and mechanical power potentiality [42, 45, 46].

$$
\begin{gathered}
H_{p}=\rho * g * H * Q \\
M_{p}=T * \omega \\
\eta=H_{p} / M_{p} \\
E=w * y * t
\end{gathered}
$$

Where,

$\mathrm{H}_{\mathrm{p}}=$ available theoretical power of water in watts

$\mathrm{M}_{\mathrm{p}}=$ mechanical power of the turbine in watts

$\eta=$ hydraulic efficiency of the turbine

$\mathrm{E}=$ energy production per year

$\rho=$ mass density of water in kilo per cubic meter

$\mathrm{g}=$ gravitational acceleration in meter per second square

$\mathrm{H}=$ effective pressure head of water in the meter

$\mathrm{Q}=$ rate of flow in cubic meter per second

$\mathrm{T}=$ torque generated by rotating shaft in Newton-meter

$\omega=$ rotational velocity in radians/second

$\mathrm{w}=$ capacity of the installation

$\mathrm{y}$ = capacity factor (capability of producing electricity in actual field condition expressed as average output to installed capacity over a period of time)

$\mathrm{t}=$ time duration, $8,670 \mathrm{~h}$ in one year

Several researchers have conducted experimental and numerical simulations to predict the efficiency of SSHT [47]. The study depicts that modern hydro turbine has $90 \%$ efficiency for converting mechanical energy to electricity by reducing the size of the turbine [43]. Computational fluid dynamics is used largely to define the interaction among various components of hydropower, but this process may not able to evaluate loss and flow behaviour [48].

\subsection{Basic Small Hydropower System}

\subsubsection{Turbine types based on the working principle}

The hydro turbine is the principal component of SSHT. According to their work principle, hydro turbines are classified into two types: impulse turbines and reaction turbines. In SSHT suitability of impulse and reaction turbine are based on available water head.

\subsubsection{Impulse turbine}

In an impulse turbine, steam strikes the blades, and moving steam circulates through the blade. Depending upon the water head, impulse turbines have several types which are shown in Table S2 (supplementary data) [49].

\subsubsection{Reaction turbine}

In this turbine, steam hits the blades axially and circulates the blades circumferentially. Depending upon the water head, the reaction turbines have several types Considering medium head (30-100m), there are two types, one is Francis Turbine and another is Pump as a turbine. For ultra-low head which indicates head below $2 \mathrm{~m}$, two main types of the turbine are Propeller Turbine and Kaplan Turbine [49].

\subsubsection{Turbine types based on economic and technological point of view}

Based on the economic and technological point of view four turbines, namely: Pelton, Francis, Kaplan, and Turgo turbine are widely used because of the low cost of the powerhouse, efficiency generation, and head suitability.

\subsubsection{Pelton turbine}

Pelton turbine consists of a split bucket surrounding particular rims where water jet from penstock is accelerated and made to flow out rapidly causing high-speed water jets to ultimately hit the blade which revolves the wheel generating torque on its shaft and generating power by converting head pressure into kinetic energy [50]. It consists of four parts: nozzle and flow regulator, runner and bucket, casing, and braking jets. Geometric design (diameter of bucket center, nozzle, jet, and width) and jet velocity of Pelton turbines depends on the speed of the runner, head of water, and rate of flow, and is calculated as using the following equations $[51,52]$ :

$$
\begin{gathered}
D_{1}=40.8 *\left(\frac{\sqrt{\mathrm{H}}}{\mathrm{N}}\right) \\
B_{1}=1.68 * \sqrt{\left.\left.\left(\frac{Q}{k \sqrt{H}}\right)\right)\right)} \\
D_{e}=1.178 * \sqrt{\frac{Q}{k \sqrt{g H}}} \\
D_{j}=0.54 * \sqrt{\left(\frac{Q}{\sqrt{H}}\right)} \\
V_{j e t}=0.97 * \sqrt{2 g H}
\end{gathered}
$$

Where,

$\mathrm{D}_{1}=$ circle diameter describing bucket center line in meters

$\mathrm{B}_{1}=$ width of bucket in meters

$D_{e}=$ diameter of the nozzle in meters

$\mathrm{D}_{\mathrm{j}}=$ diameter of the jet in meters

$\mathrm{V}_{\text {jet }}=$ jet velocity in meter per seconds

$\mathrm{g}=$ gravitational acceleration in meter per second square

$\mathrm{H}=$ net head of water in meters

$\mathrm{N}=$ speed of the runner 
$\mathrm{Q}=$ flow rate in cubic meter

$\mathrm{K}=$ number of nozzles

$\mathrm{D}_{1} / \mathrm{B}_{1}>2.7$

\subsubsection{Turgo turbine}

Turgo turbine is an impulse type turbine where high-speed water jet hits the turbine blades resulting in reverse flow. Basic parts of this turbine are nozzle, runner and buckets, casing, and breaking jets. Though the Turgo turbine is an extension of the Pelton turbine it has some physical differences. Turgo turbine has numerous advantages over Pelton turbines such as low cost of rotors, high flow rate, and control regulation of flow rate. Additionally, as there are fixed jets in the Turgo turbine it is necessary to maintain a fixed rate of flow.

\subsubsection{Francis turbine}

Francis turbine is designed in such a way that one part of the blade creates pressure difference on others for the production of electricity in hydropower stations. This turbine is the combination of both impulse and reaction types where blades revolve through the reaction and impulse force of the flow. It consists of a spiral casing, stays vanes, guided vanes, runner blades, and draft tube. Although it has several advantages, the inception of this turbine is difficult and cavitation along with dirt creates a serious problem. The geometric shape of this turbine can be found following the equations listed below [50-53]:

$$
\begin{aligned}
& D_{1}=84.5 *\left(0.31+2.49 * \frac{94 * N S}{998}\right) *\left(\frac{\sqrt{H}}{N}\right) \\
& D_{2}=\left(0.4+\frac{94.5}{N s}\right) * D 1 \\
& D_{3}=\frac{\mathrm{D} 1}{0.96+\left(3.8 * \mathrm{Ns}^{2} 10^{-3}\right)}
\end{aligned}
$$

Where,

$\mathrm{D}_{1}=$ exit diameter in meters

$\mathrm{D}_{2}=$ runner inlet diameter in meters

$\mathrm{D}_{3}=$ inlet diameter in meters

$N_{S}=\frac{N \sqrt{P_{t}}}{H_{n}^{\frac{5}{4}}}$

$P_{t}=$ turbine power in watt

$N_{S}=$ specific speed; if $N_{S}<163$ then $\mathrm{D}_{2}=\mathrm{D}_{3}$

\subsubsection{Kaplan turbine}

Kaplan turbine is principally based on axial flow reaction where water flows through a runner along the axis of rotation of the runner [43]. The reaction force of water is responsible for turning the Kaplan turbine [54]. Basic components of the Kaplan turbine are scroll casing, guide vane, draft tube, and runner blades. Upstream installed guide vane creates better efficiency of the Kaplan turbine. In Kaplan turbine, the cavitation problem due to pressure drop in the draft tube creates serious problems that can be mitigated by using stainless steel in runner blades. The basic dimension of Kaplan turbines is determined by applying the following equations [51, 52]. Table S3 (supplementary data) shows various types of turbines along with their heads and their suitable operating condition [55].

$$
\begin{gathered}
D_{1}=84.5 *\left(0.79+1.6 * 10^{-3} * N \mathrm{~s}\right) *\left(\frac{\sqrt{H}}{N}\right) \\
D_{2}=\left(0.25+\frac{94 \cdot 5}{N_{S}}\right) * D_{1}
\end{gathered}
$$

Where,

$\mathrm{D}_{1}=$ runner exit diameter in meters

$\mathrm{D}_{2}=$ runner inlet diameter in meters

\subsubsection{Penstock \& valves}

The penstock is used to lead the water to the turbine and materials should be chosen carefully so that it can handle the water pressure going towards the turbine [56]. The diameter of the penstock can be measured via equation (15) [57]. Various loss associated with penstock is delineated in Table S4 (supplementary data) [57].

$$
D=C_{1} * C_{2} * Q^{.43} * H o^{0.14}
$$

Here, $\mathrm{D}$ is the diameter of Penstock

$\mathrm{C}_{1} \& \mathrm{C}_{2}$ are energy co-efficient \& material co-efficient of the penstock,

While designing a hydropower plant there are various losses associated with penstock. This can be determined by Eq. (16).

$$
\begin{gathered}
\mathrm{H}_{\text {friction }}=\mathrm{H}_{\text {wall }}+\mathrm{H}_{\text {minor }} \\
\text { Where, } H_{\text {wall }}=\frac{.08 * F \cdot F * l * Q^{2}}{D n^{5}} \\
H_{\text {minor }}=\frac{V 2}{2 g}\left(K_{e}+K_{b 1}+K_{b 2}+K_{c 1}+K_{c 2}+\cdots+K_{v}\right)
\end{gathered}
$$

Here,

F.F $=$ Friction Factor

$\mathrm{L}=$ Length of pipe

$\mathrm{D}_{\mathrm{p}}=$ Inner diameter of the pipeline

$\mathrm{K}_{\mathrm{c} 1}, \mathrm{~K}_{\mathrm{c} 2}$ are sudden contraction ratio for the different ratio of large to the small pipe diameter.

$\mathrm{V}=$ Velocity of water

$\mathrm{K}_{\mathrm{b} 1}, \mathrm{~K}_{\mathrm{b} 2}$ are loss of heads in bends

$\mathrm{K}_{\mathrm{v}}=$ Loss of head through valves

\subsection{Previous Work through Numerical and Experimental Simulation}

Numerous studies are performed focusing on the flow behavior of fluids concerning energy transformation, velocity and pressure variation, and water head and its effect on turbines performance which are summarized in Table 5.

It is evident from Table 5 that power generation from the hydro turbine is contingent upon various factors, such as pressure drop, vane angle, tip speed ratio, flow velocity, the arrangement of the hydro turbine, position of air suction hole on the chamber wall. As a result, while installing SSHT for a specific region, these factors are crucial to design and efficiently operate the hydropower generation process. For instance, the tip speed ratio is an important factor for harvesting power from hydro energy. Up to a maximum tip speed of 6.5 is sufficient for generating efficient power. Computational Fluid Dynamic (CFD) analysis is widely used for 
Table 5. Summary of Previous Research Work Reported on SSHT

\begin{tabular}{|c|c|c|}
\hline Study & Research objective & Results \\
\hline [58] & $\begin{array}{l}\text { Use large eddy current simulation on } \\
\text { several blade and vane angles considering } \\
\text { fluid as unsteady and incompressible flow, } \\
\text { to determine the effect of pressure and flow } \\
\text { velocity on hydro turbine efficiency. }\end{array}$ & $\begin{array}{l}\text { - At } 320 \text { blade angle maximum and minimum static pressure exists. } \\
\text { - At } 600,650 \text { and } 700 \text { blade angles maximum static pressure are } 213 \mathrm{kPa}, 217 \\
\mathrm{kPa} \text {, and } 207 \mathrm{kPa} \text { respectively. } \\
\text { - Efficiency and pressure distribution of hydro turbines vary with guide vane } \\
\text { angle. }\end{array}$ \\
\hline [59] & $\begin{array}{l}\text { Numerical simulation to find the effect of } \\
\text { tip speed ratio on power generation. }\end{array}$ & $\begin{array}{l}\text { - Up to tip speed ratio } 6.5 \text {, the power output increases with increasing tip speed } \\
\text { ratio. } \\
\text { - Beyond that, the power output decreases with increasing speed ratio. } \\
\text { - High pressure exists in the font of the turbine and there is low pressure on } \\
\text { its backside. } \\
\text { - For a definite flow velocity torque decreases in a quasilinear fashion with rotating } \\
\text { velocity. }\end{array}$ \\
\hline
\end{tabular}

[60] Measure the pressure drop, energy - The pressure drop across the turbine increases with using nozzle and diffuser extraction, torque of hydro turbine. for axial flow turbines which generates more power from water energy.

- For specific water flow, velocity torque decreases in a quasi-linear fashion with increasing rotational speed.

- As in any definite rotating speed, torque reduces as subsequent flow speed decreases.

- With increasing rotating speed, power extraction increases up to the maximum power, beyond which further increasing rotating speed reduces power extraction.

[61] Investigate the shot water wheel - The acceptable efficiency of the water wheel is $74.85 \%$ which lies within performance. $\quad$ acceptable ranges (70\% to $96 \%)$.

- Analytical and actual water strike curve vane on the bucket velocity is 10.22 $\mathrm{m} / \mathrm{s}$ and $11.3 \mathrm{~m} / \mathrm{s}$ respectively.

[62] Investigate the effect of flow velocity on - Investigation shows that for NACA63415 shaped turbines, where blade with the performance of SSHT. $\quad 0.5 \mathrm{~m}$ radius, power generation increases with the flow velocity. Among three different flow velocities $(1 \mathrm{~m} / \mathrm{s}, 1.5 \mathrm{~m} / \mathrm{s}$, and $2 \mathrm{~m} / \mathrm{s})$, maximum power generation was by $2 \mathrm{~m} / \mathrm{s}$ flow velocity. For $1 \mathrm{~m} / \mathrm{s}$ to $1.5 \mathrm{~m} / \mathrm{s}$ and $1.5 \mathrm{~m} / \mathrm{s}$ to $2 \mathrm{~m} / \mathrm{s}$ flow velocity variation output increases up to 3 to 8 times respectively.

$[63,64]$

- For marine current turbines similar behavior like is observed here for flow velocity of $2.5 \mathrm{~m} / \mathrm{s}$ and $5 \mathrm{~m} / \mathrm{s}$. Investigation results show that with increasing flow velocity power generation increases up to maximum power, beyond this reverse phenomenon is seen.

Effect of the water wheel in hydro turbine. - For head below $2 \mathrm{~m}$ water, the wheel is more preferred.

- Maximum water wheel efficiency is obtained for 6 number blades rather than 8 to 12 number blades.

- 6, 8 and 12 number blades generate power of $0.041 \mathrm{~W}, 0.036 \mathrm{~W}$ and $0.026 \mathrm{~W}$ respectively.

- 6 bladed waterwheel showed 57\% improved efficiency than 12 bladed wheels.

[66] Effect of the arrangement of turbine on - Triangular arrangement along with 645 mm spacing extract maximum power hydraulic efficiency. $\quad$ in comparison with rhombus, square, series, parallel arrangement.

[67] Novel propeller turbine performance - The turbine operation largely depends on the existing flow rate and mismatching investigation through CFD analysis. of turbine rotor design.

- Flow rate affects the output which is possible to reduce by new rotor design.

[68] CFD analysis was performed to analyze air - The position of the air layer in turbine runner passage plays an important supply method for crossflow turbine. role in preventing shocking loss and recirculation flow in the runner.

- The performance of turbine largely depends on the position of the air suction hole on the chamber wall.

[69] To predict water performance of horizontal - Changing the tip shape slightly improved the cavitation performance of the axis tidal stream CFD fluent analysis is raked tip turbine.

performed. 
Table 5. Continuation

\begin{tabular}{|c|c|c|}
\hline Study & Research objective & Results \\
\hline [70] & $\begin{array}{l}\text { To evaluate performance analysis of pico } \\
\text { type turbine CFX CFD with varying runner } \\
\text { blade shape }\end{array}$ & $\begin{array}{l}\text { - Lower blade angle hydro turbine shows better performance than higher blade } \\
\text { angle. }\end{array}$ \\
\hline [71] & $\begin{array}{l}\text { CFD analysis was performed to optimize } \\
\text { the complex geometry of the Kaplan blade. }\end{array}$ & $\begin{array}{l}\text { - Change in orientation and geometry of the blade affects the turbine blade } \\
\text { efficiency. }\end{array}$ \\
\hline [72] & $\begin{array}{l}\text { Both CFD and experimental studies were } \\
\text { carried out to determine the performance } \\
\text { of the Kaplan turbine at full and partial } \\
\text { loading. }\end{array}$ & $\begin{array}{l}\text { - For total pressure at mid-span shows that at the suction side of blade pressure } \\
\text { remain below vapor pressure. }\end{array}$ \\
\hline [73] & $\begin{array}{l}\text { CFD analysis was performed to determine } \\
\text { the suitability of turbine at high head river } \\
\text { and efficiency of mini-hydropower at } \\
\text { Panching waterfall }\end{array}$ & $\begin{array}{l}\text { - For high head mini-hydropower Pelton elbow PVC turbine is most suitable. } \\
\text { - The efficiency of the Pelton turbine is } 0.961 \text { whereas the Pelton elbow PVC } \\
\text { is } 0.97 \text {. }\end{array}$ \\
\hline [74] & $\begin{array}{l}\text { Experimental and CFD analyses were } \\
\text { performed to determine axial flow pump } \\
\text { performance. }\end{array}$ & $\begin{array}{l}\text { - The axial pump can efficiently work as a turbine and is best suitable for a } \\
\text { developing country where proper turbines are not easily available. }\end{array}$ \\
\hline [75] & $\begin{array}{l}\text { Experimental study was performed to find } \\
\text { out the factor influencing rotation per } \\
\text { minute (rpm) of the water wheel. }\end{array}$ & $\begin{array}{l}\text { - Because of the higher volume retained by the triangular blade, it produces } \\
\text { high rpm than the propeller blade shape, and the } 20^{\circ} \text { nozzle angle shows maximum } \\
\text { efficiency for both propeller and triangular waterwheel. }\end{array}$ \\
\hline [76] & $\begin{array}{l}\text { CFD analysis was performed to evaluate } \\
\text { the performance of the portable micro- } \\
\text { hydrokinetic turbine. }\end{array}$ & $\begin{array}{l}\text { - Maximum power coefficient of } 0.43 \text { with } 73.7 \% \text { efficiency is achieved relative } \\
\text { to Betz limit, and propeller design portable hydrokinetic turbine may not require } \\
\text { a large civil engineering structure. }\end{array}$ \\
\hline
\end{tabular}

analyzing the performance of SSHT considering various conditions which are evident from Table 5. For analyzing the effect of various parameters such as the position of air suction hole, flow rate, tip shape, blade angle, varying head, the orientation of turbine blades, and geometry CFD analysis is extensively used which are discussed in Table 5. There are still lots of scope for development in harnessing energy from hydropower. Advanced modelling and controlling techniques to maximize the operation of the hydro turbine is need to be explored. Currently, numerous research and development are ongoing for the development of technologies of hydropower such as improving hydropower flexibility, fish-friendly hydro turbine design, energy storage with variable speed turbines etc. [77].

\section{Economic and Environmental Aspects}

Economic analysis plays an important role in the hydropower project. The capital cost involved in the hydropower project is relatively very high while operation and maintenance cost is low. Besides cost, site and environmental characteristics should also be paid attention during the feasibility stage of the project. In this section, economic and environmental analysis has been carried out.

\subsection{Economic Analysis}

Installed capacity, hydraulic head and estimated cost per kW should be considered for cost estimation of the Hydropower project. Aggidis et al. [78] developed formulas to estimate the cost of Hydropower project based on hydraulic characteristics (head and flow) of a site. The above-mentioned formulas are shown below

For head range from $(2-30 \mathrm{~m}), C=25,000 *\left(\frac{k W}{H^{0.35}}\right)^{0.65}$

For head range from $(30-200 \mathrm{~m}), C=45,000 *\left(\frac{\mathrm{kW}}{H^{0.30}}\right)^{0.60}$

Where $\mathrm{H}$ depicts head range and $\mathrm{C}$ defines cost.

The cost of electromechanical equipment (gearbox, turbine and generator) depends on the hydraulic characteristics of the sites. For small scale hydro projects, the following equations can be utilized to estimate the electromechanical equipment cost. Here, is the electromechanical equipment cost [79].

$$
C_{E M}=12,000 *\left(\frac{k W}{H^{0.20}}\right)^{0.56}
$$

In the above-mentioned costs, there was no way to differentiate between the expenses between different types of turbines. For instance, Kaplan turbine generally has two bands of flow rates that are used to find out the relationship between turbine cost and flow rate. For the flow rate between $\left(0.5 \mathrm{~m}^{3} / \mathrm{s}\right.$ and $\left.5 \mathrm{~m}^{3} / \mathrm{s}\right)$, the following equation can be used.

$$
C_{k_{1}}=15000 *(Q * H)^{0.68}
$$

For higher flow rate $\left(5 \mathrm{~m}^{3} / \mathrm{s}\right.$ to $\left.30 \mathrm{~m}^{3} / \mathrm{s}\right)$, equation 5 can be used [78]

$$
C_{k_{2}}=46,000 *(Q * H)^{0.35}
$$




\subsection{Environmental Aspects}

The increased reliability of production of energy from the renewable resources will impart positive impacts on the environment by reducing the pollution being caused by the utlisation of fossil fuels [80-85]. Ministry of New and Renewable Energy (MNRE) stated that SHS has minimal impact on flora and fauna, has minimal deforestation, and negligible submergence [86]. Besides, Kosnik also stated that the impact of hydro technology on the environment decreases with the size of the technology. This study also stated that SHS has also minimal riverine impact than large scale hydro [87]. Besides IEA also believed that the minimal environmental impact of SHS is due to construction activities and changes in water quality [7]. IEA also delineated that; flooding caused due to SHS is minimal than large scale systems. Besides no large dam is necessary for SHS and this construction period is less. Varun et al. [88] also put SHS beside wind as a sustainable energy source for energy generation since these systems emit only $31-75 \mathrm{CO}_{2} / \mathrm{kWh}$ in the atmosphere. Chhetri et al. [90] also highlighted the issue and complemented SHS as a sustainable source.

\section{Global Hydro Resource Potential}

The world hydropower installed capacity is estimated to be 1,132 GW in 2018 [90]. More than $20 \mathrm{GW}$ was added in 2018 to reach this installed capacity. More than 35\% of new installations have been made in China which as a result makes them the leader [91]. Several studies have also assessed the hydropower potential. To measure gross hydropower potential in Europe, a model-based approach was undertaken by Lehner et al. [92] with consideration of socio-economic changes and climate. The synthetic hydro network was used by Cyr et al. [93] to map the small hydropower resources. The gross, technical, and economic hydropower potentials in China were estimated as 6.1 petawatt hours per (pWh), 2.5, and $1.8 \mathrm{pWh}$, respectively [94, 95]. The hydropower potential in the United States was estimated at $2.7 \mathrm{pWh} / \mathrm{year}$ [96]. A study by Zhou et al. [96] reported that total global gross hydropower potential is estimated to be approximately $128 \mathrm{pWh} / \mathrm{year}$. The technical potential is $26 \mathrm{pWh} /$ year. The economic potential ranges from 8 to $25 \mathrm{pWh} /$ year with a cut-off cost from 0.05 to $0.15 \$ / \mathrm{kWh} /$ year [96]. In 2018, pumped storage capacity also showed an increment of $1.9 \mathrm{GW}$ and the year-end total was $160 \mathrm{GW}$ [90]. The majority of these installations are from China, Austria, and the United States.

\section{Recommendations}

In Bangladesh, the land is scarce, and developing large scale hydropower plant will bring about negative impacts such as destroying the ecosystem in the selected area, relocation of living beings, methane formation, etc. Moreover, building these kinds of large hydro plants requires a constant high flow of water flow along with high construction cost which is not feasible for a developing country like Bangladesh. The small scale Hydropower plant is gaining importance in providing sustainable hydropower in developing countries [16]. Small scale hydro turbine can be operated between $3 \mathrm{~m}$ to $10 \mathrm{~m}$ head, so it is a feasible solution for power generation like the flat landscape in Bangladesh along with low water head. Our northeastern region has a good amount of flow rate of water and head, so more micro hydro pants can be developed in these regions. Bangladesh has almost 232 rivers along with a reasonable flow rate [55]. So, developing small scale runoff hydro plants is a good way to harness more energy from hydropower. We can utilize the natural flow of these rivers to generate small scale hydropower to supply decentralized energy to the remote area people. As a result, overall pressure on the national grid will deduce. From the economic analysis, it is recommended that proper technology and site selection should be done during the feasibility study. Proper selection of these parameters is necessary for economic sustainability. The environmental analysis, it is clear that Bangladesh should avoid large scale hydro systems. Importance should be given on small scale systems since its effect on the environment is marginal.

\section{Conclusions}

Due to rapid financial advancement energy usage is on the rise in Bangladesh. The energy demand is increasing with a forecasted rate of abridgement around $7-8 \%$ per year. To achieve the goal of vision 2020, Bangladesh needs to invest in more on renewable energy projects. It will provide both ample job opportunities and green sustainable energy. Furthermore, to cope up with energy demand, the trend of renewable-based grid-connected power and increment of total generation capacity is on the rise nowadays. In this study, hydro energy potential in Bangladesh, as well as significant accomplishments are explained in detail. The assessment of modern appliances is also delineated in this study. Several latest technologies, for example, pumped hydro projects can be a suitable option to fulfil the energy demand of people. More research on the small-scale hydropower feasibility and its economic and environmental benefit is also needed to be studied for Bangladesh. Efficient control and optimized design of small-scale hydro turbines considering site locations and environmental conditions need to be assessed in the future. Furthermore, onsite data exploration such as climatic conditions, long term data analysis of flow rate in various seasons, water pressure for individual potential small scale hydropower plant needs to be further explored.

\section{Acknowledgements}

The authors would like to thank the King Fahd University of Petroleum \& Minerals, Dhahran, Saudi Arabia, and The University of Seoul for providing support in preparing this manuscript.

\section{Author Contributions}

M.I.M. (Masters Student) developed the conceptualization, methodology, and wrote the manuscript. A.A. (Ph.D.) helped in developing the conceptualization, methodology, and wrote the manuscript. H.C. (Masters Student) helped in developing the conceptualization 
and methodology of the study. M.S.R. (Masters Student) provided valuable research insights into the study and helped to review the manuscript. Y.K.P. (Professor) provided valuable research insights into the study, review the manuscript, and helped with publishing. P.C. (Bachelors Student) provided literature resources and analysis. T.C. (Masters Student) contributed to the writing and provided valuable research insights. S.M.S. (Professor) reviewed the manuscript and provided valuable insights.

\section{References}

1. Tamal C, Hemal C, Ashfaq A, et al. Energy, exergy, and sustainability analyses of the agricultural sector in Bangladesh. Sustainability 2020;12:11:1-16.

2. Tamal C, Hemal C, Nazia H, et al. Latest advancements on livestock waste management and biogas production: Bangladesh's perspective. J. Clean Prod. 2020;272:118-130.

3. Shahid A, Ashfaq A, Abdul R, Hildebrandt D, Xiu L, Young KP. Incorporation of solar-thermal energy into a gasification process to co-produce bio-fertilizer and power. Environ. Pollut. 2020;266:103-315.

4. Farrukh J, Muhammad A, Ala AM, et al. Greener and sustainable production of bioethylene from bioethanol: Current status, opportunities and perspectives. Rev Chem Eng. 2020;36:4:1-15.

5. International Energy Agency (IEA); International Energy Outlook 2016 [Internet]. [cited 02 August 2020]. Available from: http://www.eia.gov/forecasts/ieo

6. Mohsen N, Mohd MF, Mohd ZAK, Hashim H. Hybrid Renewable Energy Systems in Remote Areas of Equatorial Countries. In: IEEE Student Conference on Research and Development. IEEE; 2012; p. 11-6.

7 International Energy Agency (IEA). Total primary energy supply by fuel, 1971 and 2018 [Internet]. [cited 02 August 2020]. Available from: https://www.iea.org/data-and-statistics/charts/ total-primary-energy-supply-by-fuel-1971-and-2018.

8. Umar M M, Silva L.C.D, Bakar, MSA, Petra M I. State of the art of smoke and fire detection using image processing. Int. J. of Signal and Image Sys. Eng. 2017;10:22-30.

9. Ahmed A, Bakar MSA, Sukri RS, et al. Sawdust pyrolysis from the furniture industry in an auger pyrolysis reactor system for biochar and bio-oil production. Energy Convers. Manag. 2020;226:113-127.

10. Dennison MS, Abesha M, Umar MM. Data-set collected during turning operation of AISI 1045 alloy steel with green cutting fluids in near dry condition. Data Brief. 2020;32:106-115.

11. Abdullah A, Ahmed A, Akhter P, et al. Bioenergy potential and thermochemical characterization of lignocellulosic biomass residues available in Pakistan. Korean J. Chem. Eng. 2020;42:1-8.

12. Moogi S, Jae J, Kannapu H.P.R. Ahmed A. Park E.D. Park Y.K. Enhancement of aromatics from catalytic pyrolysis of yellow poplar: Role of hydrogen and methane decomposition. Bioresour. Tech. 2020;315:123-133.

13. Majeed K, Ahmed A, Abu Bakar MSA, et al. Mechanical and thermal properties of montmorillonite-reinforced polypropylene/rice husk hybrid nanocomposites. Polymers. 2019;11:1557-1569.
14. Javed LA, Hazlie M, Ab HAB, Hasmaini M. A. comprehensive overview of new designs in the hydraulic, electrical equipment and controllers of mini hydropower plants making it cost effective technology. Ren. Sustain. Energy. Rev. 2013;20:279-293.

15. Rajat K. PICO Power A Boon For Rural Electrification. Int. J. Sci. Res. 2012;2:159-161.

16. Mohd BF, Hambali B, Kamaruzzaman S. Quran as inspiration for implementation of pico hydro system. Int. J. Educ. Res. 2013;1:1-10.

17. Yahya AK, Munim WNWA, Othman Z. Pico-hydropower generation using dual Pelton turbines and single generator. In: Power Engineering and Optimization Conference (PEOCO) 2014; IEEE 8th International. p. 24-28.

18. Julius S, Stamp S. Local installation methods for low head pico-hydropower in the Lao PDR. Renew. Energy 2012;44:439-447.

19. Antonio G, Giuseppe TM, Francesco N, Francesco P. Technical and economic perspective for repowering of micro hydro power plants: A case study of an early century power plant. Energy Procedia. 2014;62:512-521

20. Ahmed HMA, Mohd SFM, Abdulhakim NR, Taha R. Utilization of pico hydro generation in domestic and commercial loads. Renew Sustain. Energy Rev. 2012;16:518-524.

21. Sarala AP, Ravindra MRM, Adhau PG. Mini-hydropower generation on existing, irrigation projects: case study of Indian sites. Renew Sustain. Energy Rev. 2012;16:4785-4795.

22. Loots I, Dijk MV, Barta B, Vuuren SJV, Bhagwan JN. A review of low head hydropower technologies and applications in a South African context. Renew Sustain. Energy Rev. 2015;50:1254-1268.

23. The International Renewable Energy Agency (IRENA). Renewable energy cost analysis-hydropower [Internet]. [cited 02 August 2020]. Avaiable from: www.irena.org/Publications.

24. Tick HO, ShenYP, Shing CC. Energy policy and alternative energy in Malaysia: Issues and challenges for sustainable growth. Renew Sustain. Energy Rev. 2010;14:1241-1252.

25. Yah, N. F., Oumer, A. N., Idris, M. S. Small scale hydro-power as a source of renewable energy in Malaysia: A review. Renew Sustain. Energy Rev. 2017;72:228-223

26. Jain S, Singal S. Design of water conductor system for ultra-low head hydropower project-a case study. Proceedings of the International Conference on Advances in Mechanical Engineering; 2009; Gujarat India.p.1-6.

27. Julian DH, Edward B, Yoshihide W, et al. Global resource potential of seasonal pumped hydropower storage for energy and water storage. Nat. Commun. 2020;11:1:1-8.

28. Energy and Mineral Resources Division [Internet]. Hydrocarbon Unit, Energy and Mineral Resources Division. [cited 03 August 2020]. Available from: http://www.hcu.org.bd/

29. British Petroleum (BP) [Internet]. BP Statistical Review of World Energy, British [cited 03 August 2020]. Avaiable from: http://www.bp.com/content/dam/bp/pdf/Energy-economics/ statistical-review-2018/BP-statistical-review-of-world-energy2018-full-report.pdf

30. Bangladesh Data and Statistics [Internet]. [cited 04 August 2020], Avaiable from: https://knoema.com/atlas/Bangladesh

31. Power Division. Ministry of Power, Energy and Mineral Resources. Government of the Peoples Republic of the Bangladesh. [cited 04 August 2020]. Avaiable from: 
http://www.powerdivision. gov.bd/user/index.

32. Bangladesh Power Development Board (BPDB). [Internet]. [cited 05 August 2020]. Avaiable from: http://www.bpdb.gov.bd/ bpdb.

33. International Atomic Energy Agency (IAEA) [Internet]. [cited 05 August 2020]. Avaiable from: https:/www.iaea.org/publicati

34. Chanda L, Hossain G, A green Economy in the Context of Sustainable development and poverty eradication: What are the Implications for Bangladesh?. J. of Eco. and Sus. Dev. 2014;5:119-131.

35. Prime Minister's Office Library.” [Internet]. [cited 05 August 2020]. Available: http:/lib.pmo.gov.bd/maps/. [Accessed: 18-Oct-2020]

36. Masud MH, Nuruzzaman M, Ahamed R, Ananno AA, Tomal ANMA. Renewable energy in Bangladesh: current situation and future prospect. Int. J. Sustain. Energy. 2020;39:2:132-175.

37. Halder P, Paul N, Joardder M, Sarker M. Energy scarcity and potential of renewable energy in Bangladesh. Renew Sustain. Energy Rev. 2015;51:1636-1649.

38. Rofiqul I, Rabiul I, Rafiqul AB. Renewable energy resources and technologies practice in Bangladesh. Renew Sustain. Energy Rev. 2008;12:2:299-343.

39. Local Government Engineering Department (LGED). Renewable Energy Information Network (REIN) [Internet]. [cited 02 August 2020]: Avaiable from: http://www.lged-rein.org.

40. Opportunities and challenges of hydropower development in Bangladesh:Recommendations and Possible Contribution Areas for (HPNET) [Internet]. [cited 02 August 2020]. Available from: http://www.hpnet.org/blog/context-profile-opportunitiesand-challenges-for-hydropower-development-in-bangladesh.

41. Herman JV, Kanzumba K, Sandile PK, Status of micro-hydrokinetic river technology in rural applications: A review of literature. Renew. Sustain. Energy Rev. 2014;29:625-633.

42. Abdul M, Priyono S, Aryadi S, Firman H. Design optimization of axial hydraulic turbine for very low head application. Energy Proced. 2015;68:263-273.

43. Oliver P. Small hydro power: Technology and current status. Renew Sustain Energy Rev. 2002;6:537-556.

44. Anyi M, Kirke B, Ali S. Remote community electrification in Sarawak, Malaysia. Renew. Energy. 2010;35:1609-1613.

45. Basar MF, Ahmad A, Hasim N, Sopian K. Introduction to the pico hydro power and the status of implementation in Malaysia. In: Proceedings-2011 IEEE Student Conference on Research and Development, SCOReD 2011. IEEE. p. 283-288.

46. Ayesha Z, Taslima K. Design of a Water Wheel For a Low Head Micro Hydropower System. J. Basic Sci. Technol. 2012;1:1-6.

47. Ibrahim D. Renewable energy and sustainable development: A crucial review. Renew. Sustain. Energy Rev. 2000;4:157-175.

49. Mohammed TG. Hydro power., Energy conservation: Ministry of Sciences and Technology. 2012;Iraq: Babylon Department, Hilla.p.1-12.

48. UN-Energy 2005. The energy challenge for achieving the millennium development goals, New York [Internet]. [cited 08 August 2020]. Avaiable from: https://www.undp.org/content/undp/en/ home/librarypage/environment-energy/sustainable_energy/ the_energy_challengeforachievingthemillenniumdevelopmentgoals. html.

50. Audrius Ž, David SB, George AA, Development of hydro impulse turbines and new opportunities. Renew. Sustain. Energy Rev. 2015;51:1624-1635.

51. Energy recovery in existing infrastructures with small hydropower plants [Internet]. [cited 08 August 2020]. Avaiable from: www.bt-projects.com.

52. Bilal AN. Design considerations of micro-hydro-electric power plant. Energy Procedia 2014;50:19-29.

53. Penche C. Layman's Guidebook on how to develop a small hydro site. Brussels, Belgium: Commission of the European Communities, Directorate General for Energy (DG XVII), European Small Hydropower Association (ESHA); 1998. p.1-8.

54. Ione L, Meine VD, Barta M, Van V, Jay B. A review of low head hydropower technologies and applications in a South African context. Renew. Sustain. Energy Rev. 2015;50:1254-1268.

55. Jahidul IR, Riasat IS, Hasan R, Hassan S, Fokhrul I. A Comprehensive Study of Micro-Hydropower Plant and Its Potential in Bangladesh. ISRN Renew Energy, 2012;22:1-10.

56. Dametew A. Design and Analysis of Small Hydro Power for Rural Electrification. Glo. J. Res. Eng. 2016;16:231-237.

57. Obinna AC, Emmanuel RO, Chidozie OEU. Technical Details for the Design of a Penstock for Kuchigoro Small Hydro Project. Amer. J. Renew. Sustain. Energy 2017;3:27-35.

58. Weerapon N, Sirivit T. Flow Simulations on Blades of Hydro Turbine. Int. J. Renew Energy. 2009;4:2:1-5

59. Wang J, Müller N. Performance prediction of array arrangement on ducted Composite Material Marine Current Turbines (CMMCTs). Ocean Eng. 2012:41:21-26.

60. Ji-feng W, Janusz PJ, Norbert M. A novel design of composite water turbine using CFD. J. Hydrodyn. 2012;24:11-16.

61. Din AT, Othman MY, Yaakob MY. Harvesting Energy From Flood Mitigation Ponds Using Water Wheel. In: International Conference and Exhibition on Sustainable Energy and Advanced Materials. 2011. p.1-8.

62. Hsing WN, Long JC, Ming HY, Chen BF. On design and performance prediction of the horizontal-axis water turbine. Ocean Eng. 2012;50:23-30.

63. Nishi Y, Inagaki T, Li Y, Hatano K. Study on an Undershot Cross-Flow Water Turbine with Straight Blades. Int. J. Rotating Mach. 2015;24:2:1-11.

64. Nishi Y, Inagaki T, Li Y, Omiya R, Hatano K. Research on the flow field of undershot cross-flow water turbines using experiments and numerical analysis. IOP Conf. Ser. Earth Environ. Sci. 2014;22:1-15.

65. Anurat T, Chainarong I. The effect of paddle number and immersed radius ratio on water wheel performance. Energy Procedia 2011;9:359-365.

66. Tasneem M.A, Rao NT, Idris MS, Ammar M. Numerical Simulation of Multiple Arrays Arrangement of Micro Hydro Power Turbines. Int. J. Mech. Mech. Eng. 2014;8:954-960.

67. Simpson R, Williams A. Application of computational fluid dynamics to the design of pico propeller turbines. 2006. In: Proceedings of the International Conference on Renewable Energy for Developing Countries. p.1-10.

68. Choi YD, Yoon HY, Inagaki M, Ooike S, Kim YJ, Lee YH. Performance improvement of a cross-flow hydro turbine by air layer effect. IOP Conference Series: Earth Environ. Sci. 2010;12:12-30. 
69. Lee JH., Park S, Kim, Rhee DH, Kim MC, Computational methods for performance analysis of horizontal axis tidal stream turbines. Appl. Energy 2012;98:512-523.

70. Park JH, Lee NJ, Wata JV, Hwang YC, Kim YT, Lee YH. Analysis of a pico tubular-type hydro turbine performance by runner blade shape using CFD. IOP Conf. Ser. Earth Environ. 2012;15:30-37.

71. Janjua AB, Khalil MS, Saeed M, Blade Profile Optimization of Kaplan Turbine Using CFD Analysis. Mehran Univ. Res. J. Eng. Technol. 2013;32:559-574.

72. Bijukchhe V. Comparison of experimental results of horizontal kaplan turbine with computational fluid dynamics. Master of Science Thesis, Department of Civil and Environmental Engineering, University of Iowa. 2012. p.1-6.

73. Abdul Rahman bin Mohammad. Simulation of mini hydro power based on river configuration at river upstream. Bachelor Mechanical Engineering Thesis, Faculty of Mechanical Engineering. Universiti Malaysia Pahang; 2013.

74. Alireza B, Javidpour E, Alireza R, Ahmad N. Numerical and experimental study of using axial pump as turbine in Pico hydropower plants. Renew. Energy 2013;53:258-264.

75. Lie JI. An alternative model of overshot waterwheel based on a tracking nozzle angle technique for hydropower converter. Int. J. Renew. Energy Res. 2014;4:1013-1019.

76. William CS, Jacob DB, Alparslan O. Numerical characterization of a preliminary portable micro-hydrokinetic turbine rotor design. Renew. Energy. 2015;76:234-241.

77. Kougias I, Aggidis G, Avellan F et al. Analysis of emerging technologies in the hydropower sector. Renew. Sust. Energy. Rev. 2019;113:109-125.

78. George AA, Luchinskaya E, Rothschild, David CH. The costs of small scale hydro power production: Impact on the development of existing potential. Renew Energy 2010;35:12:2632-2638.

79. Papantonis D. Small hydro power stations. Athens Simeon. 2001;12:1-16

80. Moogi S, Lingaiah N, Sai P, et al. Copper promoted Co/MgO: A stable and efficient catalyst for glycerol steam reforming. Int. J. Hydr. Energy 2020;45:57:2235-2247.

81. Radenahmad N, Haji M, Ashfaq A, Abu Bakar MS, Zaini J, Azad AK. Characterization of rice husk as a potential renewable energy source. 7th Brunei InternationalL Conference on Engineering and Technology 2018; Bandar Seri Begawan, Brunei Darussalam: IET Digital Library. p.30-34.

82. Miskat MI, Ahmed A, Chowdhury $\mathrm{H}$ et al. Assessing the Theoretical Prospects of Bioethanol Production as a Biofuel from Agricultural Residues in Bangladesh: A Review. Sustainability 2020;12:20:85-95.

83. Bakar MS, Ahmed A, Jeffery DM, et al. Pyrolysis of solid waste residues from Lemon Myrtle essential oils extraction for bio-oil production. Bioresour. Technol. 2020;318:12:2239-2244.

84. Ahmed A, Bakar MS, Hamdani R, et al. Aslam M. Valorization of underutilized waste biomass from invasive species to produce biochar for energy and other value-added applications. Environ. Res. 2020;186:109-121.

85. Ahmed A, Bakar MS, Azad AK, Sukri RS, Phusunti N. Intermediate pyrolysis of Acacia cincinnata and Acacia holosericea species for bio-oil and biochar production. Energy. C. Manag. 2018;176:393-408.

86. Tasneem A, Abbasi SA. Small hydro and the environmental implications of its extensive utilization. Renew Sustain. Energy Rev. 2011;15:2134-2143.

87. Lea K. The potential of water power in the fight against global warming in the US. Energy Policy. 2008;36:9:3252-3265

88. Varun PR, Bhat IK. Energy, economics and environmental impacts of renewable energy systems. Renew Sustain. Enegy Rev. 2009;13(9):2716-2721.

89. Chhetri AB, Pokharel GR, Islam MR. Sustainability of Micro-Hydrosystems- A case study. Energy Environ. 2009;20(4): 567-585.

90. Renewable Energy Policy Network for the 21st Century. Renewables 2019 Global Status Report; Renewable Energy Policy Network for the 21st Century: Paris, France, 2019.

91. Bernhard L, Gregor C, Vassolo S. The impact of global change on the hydropower potential of Europe: a model-based analysis. Energy Policy. 2005;33:7:839-855.

92. Jean F, Mathieu L, Gagnon Y. Methodology for the large-scale assessment of small hydroelectric potential: Application to the Province of New Brunswick (Canada). Renew Energy. 2011;36:2940-2950.

93. XiaoLin C, Xinghong L, Wei Z. Hydropower in China at present and its further development. Energy. 2010;35:11:4400-4406.

94. Wen L, Henrik L, Brian VM, Xiliang Z. Potential of renewable energy systems in China. App. Energy. 2011;88:2:518-525.

95. Douglas GH, Shane JC, Kelly SR, et al. Waterenergy resources of the United States with Emphasis on low head/low power resources, 2004. Idaho National Engineering and Environmental Laboratory. p.1-7.

96. Zhou Y, Hejazi M, Smith S, et al. A comprehensive view of global potential for hydro-generated electricity. Energy Environ. Sci. 2015;8:2622-2633. 